\title{
Role of the gut in the pathophysiology of extrahepatic biliary obstruction
}

\author{
W D B Clements, R Parks, P Erwin, M I Halliday, J Barr, B J Rowlands
}

\begin{abstract}
Background-Gram negative septic events are the commonest source of morbidity and mortality as a result of surgery in jaundiced patients. The large intestine provides the major source of Gram negative bacteria in mammals and is implicated in the pathogenesis of systemic endotoxaemia in obstructive jaundice. Bile salts have an important part in maintaining indigenous microecological

increase in the Gram negative aerobic population, which may account for translocation in the early stages of biliary obstruction. As the duration of biliary obstruction increases systemic endotoxaemia is a consistent feature which, combined with factors such as immunological depression and physical disruption of gut barrier function, may promote bacterial translocation perpetuating systemic sepsis.
\end{abstract} homeostasis through their emulsifying properties.

Aims-The aim was to investigate the effects of biliary obstruction and isolated external biliary diversion on gastrointestinal structure and caecal bacterial flora in relation to bacterial translocation.

Method-Six groups of adult male Wistar rats were studied (no operation, sham operated, and bile duct ligated (BDL) for one and three weeks and a choledochovesical fistula (CDVF) for one week). At the end of the study period plasma was assayed for evidence of endotoxaemia and the animals were tested for bacterial translocation to the mesenteric lymph node complex (MLNC), liver, lungs, and spleen. Quantitative and qualitative bacteriological studies were performed on the caecal contents and segments of colon and terminal ileum were washed and prepared for histological assessment.

Results-Bacterial translocation was significantly increased in the BDL1 $(68 \cdot 8 \%)$ and BDL3 $(60 \%)$ groups compared with the sham $1(6 \cdot 3 \%)$, sham $3(9 \cdot 1 \%)$, No operation (0\%), and CDVF1 (16.7\%) groups. Although translocation was more pronounced in the BDL1 group, this was almost exclusively to the MLNC compared with the more widespread translocation to other organs in the BDL3 group. The BDL3 group was the only group with significantly raised concentrations of endotoxin and anticore glycolipid. The caecal Gram negative aerobic counts were significantly increased in the BDL1 and CDVF1 groups compared with all other groups. There was evidence of structural abnormalities in the terminal ileum of rats jaundiced for three weeks, but not in the other groups.

Conclusions-Biliary obstruction for one and three weeks promotes bacterial translocation although the mechanisms may be different. Absence of intralumenal bile results in a significant but self limiting
(Gut 1996; 39: 587-593)

Keywords: bacterial translocation, jaundice, sepsis, bile salts.

Perioperative Gram negative septic events complicate the outcome of jaundiced patients undergoing invasive diagnostic and therapeutic procedures. ${ }^{1-3}$ Systemic endotoxaemia is implicated in the high morbidity and mortality in this patient population. ${ }^{4}$ The mechanism of endotoxaemia and the pathophysiological sequence of events in obstructive jaundice remains unclear.

The two main physiological components of extrahepatic biliary obstruction are firstly, obstruction of the biliary tree with a concomitant rise in intraductal biliary pressure, and secondly, interruption of bile flow to the gastrointestinal tract. Mononuclear phagocytic function is depressed in obstructive jaundice ${ }^{6-8}$ and some authors have shown the passage of viable enteric bacteria to normally sterile extraintestinal sites in murine models of biliary obstruction. ${ }^{9-10}$ Both mechanisms are probably complementary in the development of systemic endotoxaemia. This study investigates the effects of increasing duration of biliary obstruction and external biliary diversion on the indigenous microecology of the gastrointestinal tract in relation to bacterial translocation.

\section{Methods}

\section{Experimental design}

Adult Wistar rats $(250-300$ g) from our breeding colony were housed in groups of four under constant temperature $\left(22^{\circ} \mathrm{C}\right)$ and humidity with 12 hour dark/light cycles and allowed standard laboratory animal feed (Robert Morton and Co Ltd, Ballymena, UK) and water ad libitum at all times throughout the experimental period. Rats were assigned to one of six groups: control (no operation), bile duct ligation, (BDL) and sham operated for a 
period of one or three weeks (control $(n=14)$, BDL1 $(n=16)$, sham1 $(n=16)$, BDL3 $(n=10)$, sham $3(n=11)$ ), and a further group was studied one week after sterile external biliary diversion by means of a choledochovesical fistula (CDVF1 $(n=4))$.

\section{Operative procedures}

All procedures were performed observing strict asepsis under general anaesthesia, established using intramuscular ketamine $(6 \mathrm{mg} / 100 \mathrm{~g}$; Parke-Davis Veterinary, Gwent, UK) and xylazine $(0.7 \mathrm{mg} / 100 \mathrm{~g}$ (Bayer UK Ltd, Bury St Edmunds, UK). The method described by Lee et al was employed for bile duct ligation. In brief, the common bile duct was mobilised in the upper abdomen via a $1 \mathrm{~cm}$ incision, doubly ligated using 5-0 silk, and divided. ${ }^{11}$ Sham operated rats had the bile duct mobilised but not ligated. The choledochovesical fistula was performed in a fashion originally described by Diamond and Rowlands in which a fine bore silastic cannula (internal diameter 0.51 $\mathrm{mm}$, external diameter $0.94 \mathrm{~mm}$, DowCorning, Michigan, USA) was introduced into the proximal bile duct and doubly ligated in situ with 5-0 silk sutures. ${ }^{12}$ Once there was satisfactory bile flow from the distal end of the cannula, the cannula was inserted into the dome of the bladder and sutured in place using a 5-0 silk purse string suture. All abdominal incisions were closed in two layers using 3-0 chromic catgut.

At the end of the study period animals were deeply anaesthetised, $2 \mathrm{ml}$ of venous blood was collected in glass endotoxin free tubes and placed on ice before centrifugation (15 minutes at $2000 \mathrm{~g}$ ) at $4^{\circ} \mathrm{C}$. Plasma samples were aliquoted and stored at $-70^{\circ} \mathrm{C}$ for subsequent assay. Animals were tested for bacterial translocation and small and large intestine sampled for histopathological examination.

\section{Testing for translocation of bacteria}

Under general anaesthesia a midline laparotomy was performed and swabs for bacteriological analysis were taken from the peritoneal cavity. Subsequently $3 \mathrm{ml}$ blood was collected from the portal vein for aerobic and anaerobic culture using the radiometric Bactec 460 (Becton Dickinson, Towson, MD, USA). Blood cultures were read on days $1,2,4$, and 7 at a threshold of 20 and 30 for anaerobes and aerobes respectively. Positive blood cultures were plated out on appropriate media and identified by standard bacteriological techniques.

The right lobe of the liver, and the spleen, right lung, mesenteric lymph node complex, and caecum were removed and each placed in preweighed sterile glass bottles containing sterile prereduced brain heart infusion (BHI) medium. The bottles were transferred to an anaerobic cabinet (MK3 anaerobic work station, Don Whitley Scientific Ltd, Shipley, Yorkshire, UK) in which tissue homogenates were prepared in $2 \mathrm{ml}$ BHI using sterile mortars and pestles and a homogeniser (Sorvall
Omnimixer, Ivan Sorvall Ltd, Norwalk, CT, USA). Serial dilutions of the caecal homogenate ranging from $10^{-3}$ to $10^{-7}$ were prepared in prereduced BHI. A total of $100 \mu \mathrm{l}$ aliquots of homogenates were cultured on blood agar, chocolate agar, McConkey agar, tryptic soy agar, and in cooked meat broth. All plates except those for culture of the strict anaerobes were removed from the anaerobic cabinet and incubated at $37^{\circ} \mathrm{C}$ for 48 hours. Anaerobes were cultured for five days. Aliquots of broth were plated out the next day on the four standard agar plates. After the appropriate incubation periods, individual colonies were counted and each organism plated out for purification. Organisms were identified and quantified as colony forming units /g tissue (cfu/g) using the formula:

\section{$\mathrm{N} \times \mathrm{D} \times 2 \times 10 / \mathrm{W}$}

where $\mathrm{N}=$ number of colonies on the plate; $\mathrm{D}=$ dilution inoculated on the plate; $\mathrm{W}=$ weight of specimen $/ \mathrm{g} ; 2=2 \mathrm{ml} \mathrm{BHI} ; 10=$ innoculum $(0 \cdot 1 \mathrm{ml})$.

\section{Histological assessment}

A $1 \mathrm{~cm}$ segment of ascending colon and terminal ileum was excised, lavaged with normal saline, and then fixed with $3 \%$ glutaraldehyde, processed by conventional methods, and embedded in paraffin wax. Ultrathin $(1 \mu \mathrm{m})$ sections were cut and stained by haematoxylin and eosin and examined with a Leitz Laborlux $\mathrm{K}$ microscope.

\section{Plasma assays}

Bilirubin concentrations were assayed using a standard biochemical technique and expressed in $\mu \mathrm{mol} / 1$. Endotoxin concentrations were assayed using the quantitative Limulus lysate chromogenic assay (Coatest endotoxin, Kabi Diagnostica, Molndal, Sweden) and expressed in $\mathrm{pg} / \mathrm{l}$. The samples were pretreated by a 10 -fold dilution in pyrogen free water and heat treatment for five minutes at $85^{\circ} \mathrm{C}$ to negate the effects of plasma inhibitory factors on the assay. Endotoxin present in the plasma converts a proenzyme to an active enzyme, which acts on a chromogenic substrate producing a colormetric change, detectable spectrophotometrically at an absorbence wavelength of 405 $\mathrm{nm}$.

Anticore glycolipid antibody concentrations - the relative concentration of antibodies to the core glycolipid region of lipopolysaccharide were measured using an enzyme linked immunosorbent assay (EndoCab, Celltech, Slough, England). This technique, originally described by Scott and Barclay, employs microtitre plates coated with a cocktail of four rough endotoxin strains complexed with polymyxin $\mathrm{B}$ sulphate. ${ }^{13}$ Prediluted samples were incubated with the solid phase, and bound rat IgG detected using a specific antirat IgG-peroxidase conjugate (Serotec Ltd, Oxford, England). The results are expressed as a percentage of control values obtained from normal rats. 
TABLE I Summary of results displaying the incidence of bacterial translocation, caecal Gram negative aerobic counts, systemic concentrations of bilirubin, endotoxin, and anticore glycolopid antibody (ACGA)

\begin{tabular}{lcccccc}
\hline Model & No operation & Sham 1 & BDL1 & CDVF1 & Sham3 & $B D L 3$ \\
\hline BT (\%) & 0 & $6 \cdot 3$ & $68 \cdot 8^{\star \star}$ & $16 \cdot 7$ & $9 \cdot 1$ & $60^{\star}$ \\
Bilirubin (umol/1) & $1 \cdot 5(0 \cdot 6)$ & $1 \cdot 1(0 \cdot 1)$ & $151(4 \cdot 1)^{\star \star}$ & $1 \cdot 35(0 \cdot 3)$ & $1 \cdot 3(0 \cdot 1)$ & $147(7 \cdot 4)^{\star \star}$ \\
Endotoxin (pg/ml) & $0.5(1 \cdot 2)$ & $1 \cdot 7(1 \cdot 1)$ & $26 \cdot 9(20 \cdot 0)$ & $1 \cdot 6(1 \cdot 6)$ & $1 \cdot 5(0 \cdot 8)$ & $34 \cdot 5(16)^{\star \star}$ \\
ACGA (\% increase) & $92(35 \cdot 7)$ & $109(11)$ & $163(33 \cdot 8)$ & $129(8 \cdot 7)$ & $98 \cdot 4(10 \cdot 3)$ & $239(37 \cdot 5)^{\star \star}$ \\
Gram negative aerobes & $5.93(0 \cdot 22)$ & $5 \cdot 52(0 \cdot 24)$ & $6 \cdot 52(0 \cdot 30)^{\star}$ & $7 \cdot 17(0 \cdot 45)^{\star \star}$ & $5 \cdot 34(0 \cdot 35)$ & $5 \cdot 44(0 \cdot 50)$ \\
(-log 10 cfu/g) & & & & & &
\end{tabular}

Results are mean (SEM). ${ }^{\star} \mathrm{p}<0 \cdot 05 ;{ }^{\star \star} \mathrm{p}<0 \cdot 01$.

Statistical analysis

Data analysis was performed on an Olivetti M300-30 microprocessor using Arcus professional software (Iain Buchan, Oxford, UK). Non-parametric statistical analysis (Fisher's exact test, Kruskal-Wallis, and Mann-Whitney $\mathrm{U}$ tests) was used throughout and significance accepted at the $5 \%$ level.

\section{Results (Tables I, II, and III)}

General changes and plasma assays

Rats undergoing bile duct ligation were clinically jaundiced within three to four days and were maximally jaundiced by one week with conjugated bilirubin present in the urine. Animals jaundiced for one week were sprightly with similar energy levels to controls and no overt evidence of ill health despite experiencing a more pronounced initial weight loss after surgery (Fig 1). With increasing duration of bile duct ligation animals were less energetic although appetite and weight gain were similar to those of control rats (Fig 1). Rats jaundiced for three weeks had significantly increased serum concentrations of both endotoxin and anticore glycolipid compared with the sham operated group at three weeks $(p<0.001$, Mann-Whitney U test). Although there were sporadic increases in both endotoxin and

TABLE II Prevalence of translocating organisms seen in the various groups expressed as the number of episodes in which an individual organism was recovered and its percentage of total translocation episodes within individual groups

\begin{tabular}{llllll}
\hline Translocating organism & $B D L 1$ & $B D L 3$ & Sham1 & Sham3 & CDVF1 \\
\hline E coli & $16(73)$ & $3(20)$ & & & $2(100)$ \\
Gram +ve bacillus & $2(9)$ & $5(33)$ & & & \\
Gram -ve bacillus & $1(4 \cdot 5)$ & $1(6 \cdot 7)$ & & & \\
Enterobacter species & $1(4 \cdot 5)$ & $1(6 \cdot 7)$ & $1(100)$ & & \\
Streptococcus species & $2(9)$ & $2(13 \cdot 3)$ & & & \\
Moraxella species & & $1(6 \cdot 7)$ & & $1(50)$ & \\
Pasteurella species & & $1(6 \cdot 7)$ & & $1(50)$ & \\
Acinetobacter species & & $1(6 \cdot 7)$ & & & \\
Anaerobic bacillus & & $1(9 \cdot 7)$ & & & \\
\hline
\end{tabular}

Values in parentheses are \%.

TABLE III Qualitative alterations in the caecal Gram negative bacteria displayed as percentage prevalence seen in control groups and jaundiced rats

\begin{tabular}{lcccccc}
\hline Organism & Control & Sham1 & Sham3 & BDL1 & BDL3 & CDVF1 \\
\hline E coli & 83 & 100 & 67 & 100 & 100 & 100 \\
Pseudomonas & 17 & 22 & 17 & 63 & 33 & 83 \\
Pasteurella & 50 & 11 & 33 & 75 & 33 & 67 \\
Shigella & 0 & 11 & 0 & 25 & 0 & 33 \\
Moraxella species & 17 & 0 & 67 & 13 & 50 & 33 \\
Klebsiella species & 17 & 0 & 0 & 0 & 33 & 17 \\
Enterobacter species & 0 & 0 & 17 & 0 & 25 & 0 \\
Proteus species & 0 & 0 & 0 & 0 & 8 & 0 \\
Acinitobacter & 17 & 0 & 50 & 0 & 17 & 0 \\
Alcaligenes faeces & 0 & 0 & 0 & 0 & 8 & 0 \\
\hline
\end{tabular}

ACGA concentrations in rats jaundiced for one week this was not a consistent finding and was not significantly different from the sham operated animals at one week and the CDVF1 group (Table I).

\section{Bacterial translocation}

Bile duct ligation for both one and three weeks resulted in a significantly increased incidence of bacterial translocation compared with rats undergoing sham operation and external biliary diversion (Table I). Bacterial translocation was maximal (11 of 16 animals $(68 \%))$ in rats jaundiced for one week and translocation was predominantly to the mesenteric lymph node complex (MNLC $64 \%$, portal blood $18 \%$, liver $18 \%$ ). The organism most often retrieved was Escherichia coli. In rats jaundiced for a three week period the incidence of translocation was similar (six of 10 animals $(60 \%)$ ) but was more widespread to other sites - namely, the liver, lungs, and spleen (MNLC 14\%, portal blood $14 \%$, liver $14 \%$, lung $36 \%$, spleen $22 \%$ ) with diversity of the translocating organism (Table II). Only one of six rats undergoing sterile external biliary drainage for one week had evidence of translocation.

\section{Bacteriology}

A significant increase in the Gram negative aerobic population was also noted in the BDL1 group and CDVF group compared with the sham 1 and BDL3 groups (Table I). Both BDL groups seemed to experience qualitative alteration in the resident caecal microflora with a more diverse pattern of bacterial species isolated compared with control groups (Table III), representing a qualitative disruption of the indigenous microflora.

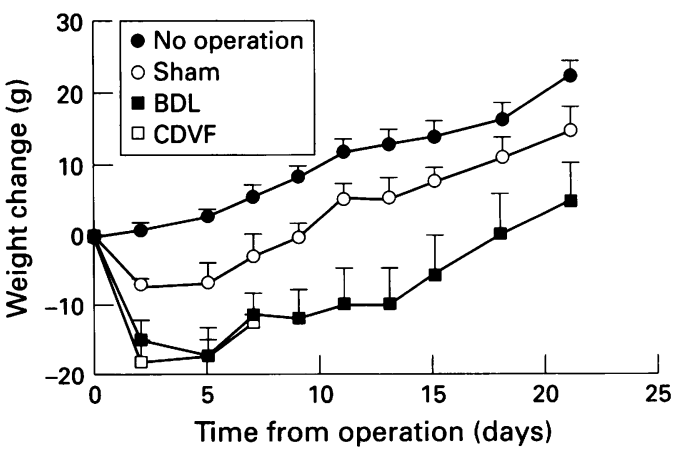

Figure 1: Weight change (g (SEM)) in the bile duct ligation (BDL) and control rats (no operation and sham) over the period of the experiment. 

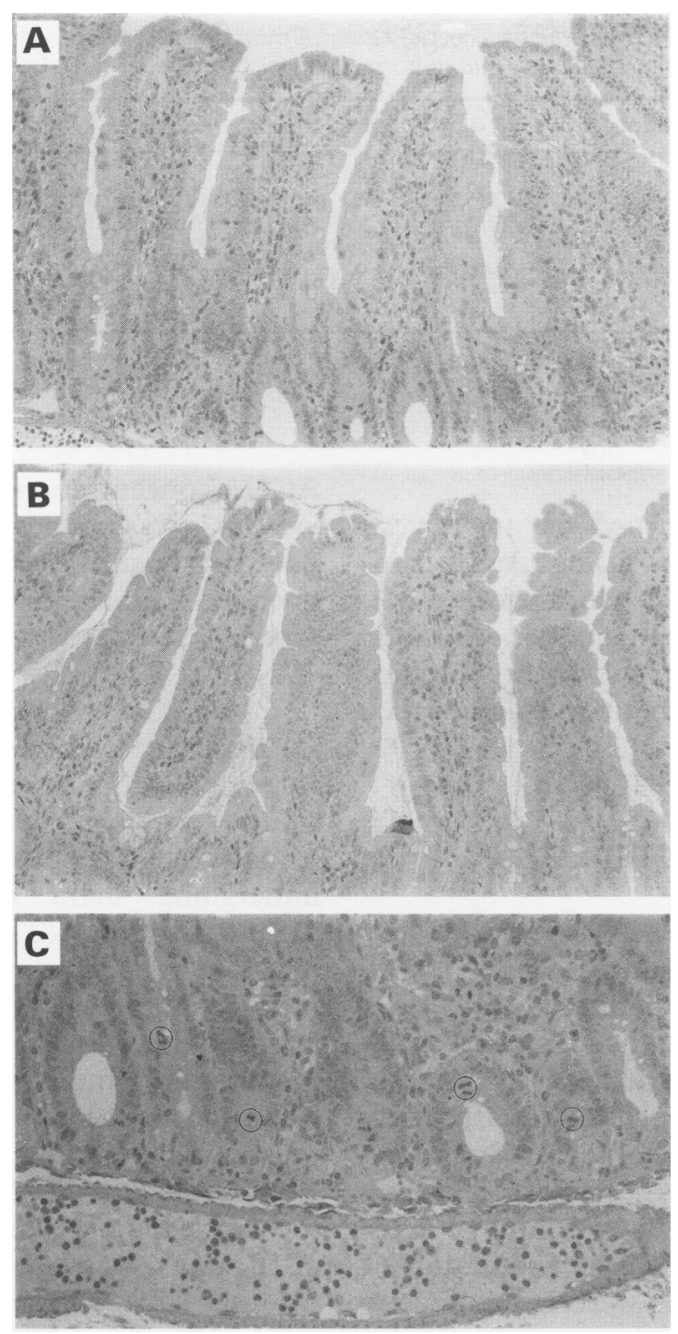

Figure 2: Low power light micrographs representative of the terminal ileum of the $B D L$ rats $(A)$ and sham operated rats (B). There is considerable blunting of the villi with loss of villus height in the jaundiced rat intestine compared with the control group. (C) Higher power view of the Peyer's patch at the base of the intestinal crypt in a jaundiced rat. It shows engorgement of a Peyer's patch with an increase in the number of mitotic figures (circles) in the lamina propria of the terminal ileum.

Apart from the qualitative and quantitative changes described there were no other differences detected in the caecal microflora.

\section{Histology}

Histological analysis of the terminal ileum in the BDL3 group disclosed non-specific features of small intestinal damage - namely, flattening of the villi with enlargement of Peyer's patches and an increase in the number of mitotic figures (Fig 2A, B, and C). There was no evidence of mucosal injury in either the small or large bowel of the other groups. These histological changes are purely descriptive; however, refined structural and ultrastructural morphometric image analysis of the small intestine is presently underway in our laboratory.

\section{Discussion}

Jaundiced patients undergoing invasive diagnostic and therapeutic procedures are at significant risk of serious perioperative compli- cations and death. ${ }^{14-16}$ Gram negative sepsis constitutes the bulk of this morbidity and mortality, but renal dysfunction, coagulopathy, deficient wound healing, and gastrointestinal haemorrhage are well recognised. ${ }^{17-20}$

The pathophysiology of the complications seen in extrahepatic biliary obstruction remains unresolved, but there is increasing evidence to support the role of systemic endotoxaemia. Since Wardle and Wright first demonstrated an association between renal dysfunction and endotoxaemia in a cohort of jaundiced patients numerous authors have concurred with this finding in both the clinical and experimental setting. ${ }^{21-24}$

Endotoxin is a heat stable constituent of the outer wall of Gram negative bacteria with an $\mathrm{O}$-specific side chain and a highly conserved inner core, which, when present in the systemic circulation, has the capacity to initiate a far reaching physiological response through the release of vasoactive inflammatory cytokines from cells of the mononuclear phagocytic system..$^{25-27}$ Although exposure to endotoxin is important for the development of the hosts' imune response, when exposed to high systemic concentrations the effects are exclusively detrimental. There have been two main hypotheses for the mechanism of systemic endotoxaemia in obstructive jaundice. In the mammalian system the largest reservoir of Gram negative organisms is the gastrointestinal tract and more specifically the colon. Under normal physiological circumstances the gut mucosal barrier is impervious to the passage of bacteria into the sterile environment of the peritoneal cavity, portal circulation, and other organ systems such as the liver, lungs, and spleen. The population of Kupffer cells comprises the bulk of the mononuclear phagocytic system and these are strategically located at the confluence of portal venous drainage for the sequestration and elimination of bacteria and portal endotoxins.

Any functional or structural disturbance in either the intestinal mucosal barrier or Kupffer cell population will result in the escape of bacteria and endotoxin to the portal circulation and subsequently to systemic sites, which are normally sterile. This phenomenon was coined 'bacterial translocation' and has been shown to occur under the influence of various pathological insults. ${ }^{28-31}$ Although there are protean circumstances in which bacterial translocation has been shown to occur, several unifying factors are implicated in its pathophysiology namely, physical injury to the intestinal mucosa, bacterial overgrowth, host immune dysfunction, and endotoxaemia. ${ }^{32-34}$

\section{Physical intestinal injury}

In 1987, Bergesen et al carried out an experiment in which rats underwent biliary diversion by way of a choledochocolic fistula. This absence of intraluminal bile' salts did not result in an alteration in villus height, weight, protein, or DNA content in the mucosal scrapings of the terminal ileum although there was an increase in the excretion of urinary 
indican, an indirect measurement of small intestinal bacterial overgrowth. ${ }^{35}$ More recently, Deitch et al demonstrated morphological changes in the small intestine in a rodent model of biliary obstruction and Ding et al described non-specific abnormalities in the mucosa of the small intestine. ${ }^{9} 10$ This physical injury may contribute to breakdown of gastrointestinal barrier function and consequently promote bacterial translocation. Deitch et al have found this phenomenon in rats to which endotoxin has been given parenterally ${ }^{31}$ and attributed these morphological changes to a selective ischaemia-reperfusion injury of the ileocaecal segment of the gastrointestinal tract $^{36}$ effected via the xanthine oxidase pathway. He showed that this effect could be abrogated using the specific xanthine oxidase inhibitors allopurinol and ibuprofen. ${ }^{37}$ Other than this preliminary data there is no conclusive evidence supporting the role of physical injury to the intestinal mucosa as the primary insult promoting bacterial translocation in biliary obstruction.

\section{Absence of intraluminal bile and microfloral disturbances}

Burke et al investigated the effects of biliary diversion on intestinal microflora from the stomach, mid-jejunum and caecum. ${ }^{38}$ Animals were pair fed and caged on wire mesh to limit coprophagy. They were killed after five days of external biliary diversion and although there was an increase in coliforms and Proteus species, this was most pronounced in the proximal small intestine and was found in the rats undergoing biliary diversion and pair fed animals compared with the control group. Their data were interpreted as an effect of semistarvation as opposed to the loss of intraluminal bile salts. Both Deitch et al and Ding et al have demonstrated a quantitative disturbance in the caecal microflora in the rodent model of biliary obstruction and Slocum et al intimated that this disturbance in the Gram negative aerobic population was attributable to the loss of the constraining effects of luminal bile salts. ${ }^{910}{ }^{39}$ Most of the bacteriological studies on the effects of biliary obstruction or diversion on the indigenous intestinal microflora have been carried out in rodent models, which may not directly reflect what happens in humans. Rats are coprophagic, which means that the upper small bowel will not be sterile and over $90 \%$ of secretory IgA is secreted in the bile; both characteristics are particular to rodents. These are important considerations when interpreting results of bacteriological studies performed in rodent models.

\section{Immune dysfunction}

It is well recognised that extrahepatic biliary obstruction induces specific and non-specific depression in host immune status; however, the mechanism for this remains unclear. ${ }^{40-43}$ There are many reports of cellular immune dysfunction and Greve et al suggested that depression of $T$ cell function was a direct effect of systemic endotoxaemia. ${ }^{44}$ Gautreaux et al have shown that $\mathrm{T}$ lymphocytes situated in the gastrointestinal mucosa, Peyer's patches, and mesenteric lymph node complex have an important role in the prevention of bacterial translocation. ${ }^{45}$ It has also been shown that $T$ cell mitogen suppression occurs as a secondary effect of bacterial translocation. ${ }^{46}$ There is a large body of evidence showing impaired mononuclear phagocytic system (MPS) function in obstructive jaundice ${ }^{47} 48$ and although macrophages are implicated in the transport of viable microorganisms from the gut lumen ${ }^{49}$ to the mesenteric lymph node complex, liposome mediated macrophage elimination has been shown to promote bacterial translocation in the zymosan model. Interestingly, this produced a reduction in overall mortality, probably through the abrogation of endotoxin mediated cytokine release from the mononuclear cell population..$^{50}$

\section{Endotoxaemia}

Endotoxaemia has been reported as a sporadic, inconsistent finding in obstructive jaundice; however, with the refinements in the Limulus lysate chromogenic assay ${ }^{51}$ and the development of the EndoCab assay for the direct measurement of antibodies produced to the highly conserved inner core region of circulating endotoxins ${ }^{13}$ there is little doubt that endotoxaemia occurs and has a key role in the pathophysiology of biliary obstruction. The coexistence of these physiological states in biliary obstruction may well promote bacterial translocation.

When examining the factors involved in bacterial translocation it is important to consider the role of intraluminal constituents, such as bile salts, which have a constraining role on the indigenous colonic microflora through their emulsifying properties serving to detoxify lumenal endotoxins and maintain the homeostatic pattern of the indigenous flora. ${ }^{52}$ Secretory IgA is present in large concentrations in bile, particularly in the rodent, and its absence from the gastrointestinal tract may result in a disturbance in the local immunological milieu. ${ }^{53} 54$

The bacterial defences of the bowel reside in two interesting properties of the colonic bacterial flora. Firstly, the ability to maintain communal stability (bacterial antagonism), which involves competition for nutrients, adhesion sites, and the production of antimicrobial factors. ${ }^{55}$ Secondly, normal intestinal flora can prevent colonisation by exogenous bacteria (colonisation resistance). The obligate anaerobes are thought to play an important part in colonisation resistance due to their close association with the intestinal epithelium constituting a barrier limiting attachment of potential pathogens to the mucosal epithelium. ${ }^{56}$ Colonic bacteria can produce short chain fatty acids (acetate, proprionate, and butyrate), all of which provide fuel for the colonocyte. ${ }^{57}$ To date most authors have employed standard bacteriological techniques 
to quantify and qualify bacterial translocation, although it would seem from recent reports that it may not be sufficient to characterise microorganisms solely by their species. ${ }^{58}$ It has been shown using biochemical fingerprinting that certain bacterial phenotypes have a propensity for translocation and it may be more important to assess the qualitative constitution of specific bacterial species in the faecal flora as opposed to isolated alterations in quantitative counts. ${ }^{59}$

The aim of this study was to evaluate the effects of increasing duration of biliary obstruction on bacterial translocation in relation to temporal alterations in the indigenous microecology over a three week period.

\section{Bile salts}

Bile salts have been shown to inhibit the growth of intestinal bacteria in both the experimental and clinical setting. ${ }^{61} 62$ The mechanism is unclear. However, this has been attributed to their detergent action in which the bacterial cell membrane integrity is compromised and the endotoxin molecule is broken down into inert subunits or formed unabsorbable micellar aggregates. ${ }^{63}$ In clinical studies oral treatment with bile acids has been shown to reduce systemic endotoxaemia and the incidence of renal failure in jaundiced patients. ${ }^{6465}$ Ding et al also showed a reduction in bacterial translocation in jaundiced animals to which bile salts were administered enterally. ${ }^{66}$

\section{Study commentary}

Bacterial translocation was demonstrable in animals jaundiced for both one and three weeks. The shorter period of biliary obstruction resulted in significant overgrowth of Gram negative aerobic bacteria and a greater incidence of translocation, although this was predominantly to the mesenteric lymph node complex. With increasing duration of bile duct ligation, animals had a lower incidence of bacterial translocation and no significant quantitative disturbance in the microecological floral pattern. Despite this, a broader range of vegetative species were isolated from the caecum with wider dissemination to the portal blood, liver, lungs, and spleen. Consistent with the increased systemic exposure, high plasma concentrations of anticore glycolipid antibody and endotoxin were demonstrable. In the animals jaundiced for a three week period the site where most translocation was found was the lungs and these data support the observation of Katz et al, who recognised that in the absence of normal Kupffer cell function the pulmonary system compensates with greater bacterial trapping. ${ }^{60}$ Pulmonary alveolar macrophages (PAMs) have less bactericidal potential than Kupffer cells, which may permit bacteria to survive in a state of intracellular symbiosis resulting in activation of the PAM, perpetuating the inflammatory response in the lungs. These data concur with the findings of Ding et al and raise the possibility that there may be two distinct mechanisms responsible for the bacterial translocation seen at the different time points after ligation of the bile duct.

After one week of bile duct ligation absence of intraluminal bile salts results in the overgrowth of Gram negative aerobes, which is the most likely mechanism for translocation. The limitation of translocation to the mesenteric lymph node complex and the low plasma concentrations of endotoxin and anticore glycolipid antibodies in the BDL1 group may reflect normal mononuclear phagocytic function at this stage of biliary obstruction. In the CDVF group, in which bile flow was externally diverted from the gastrointestinal tract in the absence of biliary obstruction there was a similar overgrowth in the Gram negative aerobic population. No bacterial translocation was demonstrable in this group despite the microecological disturbances, although Slocum et al showed not only disturbances in lumenal floral counts but also bacterial translocation in rats undergoing CDVF, reinforcing the argument that bacterial translocation seen in the early stages of biliary obstruction probably is directly related to a disturbance in the indigenous microflora occurring as a consequence of the absence of intraluminal bile salts.

With the increasing duration of biliary obstruction the intraluminal microecological disturbances are no longer demonstrable. It is plausible that with increased duration of biliary obstruction the systemic concentrations of bile acids increase proportionately and may diffuse back to the intestinal tract exerting their homeostatic effects on the intestinal flora. Despite this normalisation in the microflora the efficiency of the MPS, specifically the Kupffer cell population, to sequester and clear endotoxaemia is impaired. Depression in the phagocytic potential of Kupffer cells may result from physical effects of biliary obstruction and raised intraductal pressure, the toxic effects of high bile salt concentrations, portal endotoxins, and inflammatory mediators locally in the liver. This is reflected in increased concentrations of endotoxin and anticore glycolipid antibody systemically and the broader pattern of bacterial translocation to other organ systems. Depression of host immune function with the concomitant effects of systemic endotoxaemia on gastrointestinal mucosal integrity may be responsible for bacterial translocation seen in the later stages of biliary obstruction.

In conclusion, we postulate that absence of intraluminal bile salts results in bacterial overgrowth and bacterial translocation in the early stages of biliary obstruction. With progression of biliary obstruction there is loss of the constraining effects of MLNC on enteric bacteria resulting in systemic dissemination. This may well be related to deficient mononuclear phagocytic function. With the 'spillover' of portal endotoxin systemically, there is a circuitous effect on gastrointestinal mucosal integrity resulting in further bacterial translocation and perpetuation of the systemic septic inflammatory response. 
1 Holman JM, Rikkers LF, Moody FG. Sepsis in management of complicated biliary disorders. Am $\mathcal{F}$ Surg management of comp

2 Armstrong CP, Dixon JM, Taylor TV, Davies GC. Surgical experience of deeply jaundiced patients with bile duct obstruction. Br F Surg 1984; 71: 234-8.

3 Lai EC, Chu KM, Lo CY, et al. Surgery for malignant obstructive jaundice: analysis of mortality. Surgery 1992; 112: 891-6.

4 Diamond T, Rowlands BJ. Endotoxaemia in obstructive jaundice. HPB Surg 1991; 4: 81-4.

5 Bailey ME. Endotoxin, bile salts and renal function in obstructive jaundice. Br F Surg 1976; 66: 392-7.

6 Drivas G, James O, Wardle N. Study of the reticuloendothelial phagocytic capacity in patients with cholestasis. thelial phagocytic capacit

7 Dunn CW, Horton JW. Impairment of mononuclear phagocyte system function in obstructive jaundice. FASEB F 1989; 3: A930.

8 Clements WDB, Halliday MI, McCaigue MD, Barclay GR, Rowlands BJ. The effects of extrahepatic obstructive
jaundice on Kupffer cell clearance capacity (KCCC). Arch Surg 1993; 128: 200-5.

9 Deitch EA, Sittig K, Li M, Berg R, Specian RD. Obstructive jaundice promotes bacterial

10 Ding JW, Andersson $R$, Soltesz V, Willen $R$, Bengmark $S$. Obstructive jaundice impairs reticuloend $R$, Bengmark and promotes bacterial translocation in the rat. $\mathcal{F}$ Surg Res and promotes bact

11 Lee E. The effect of obstructive jaundice on the migration of reticuloendothelial cells and fibroblasts into early experimental granulomata. Br f Surg 1972; 59: 875-7.

12 Diamond T, Rowlands BJ. Choledochovesical fistula: a model for sterile 'external' biliary drainage. Surg Res Comm 1990; 8: 131-8.

13 Scott BB, Barclay RG. Endotoxin-polymyxin complexes in an improved enzyme-linked immunosorbent assay for IgG antibodies in blood donor sera to gram-negative endotoxin core glycolipids. Vox Sang 1987; 52: 272-80.

14 Sikora SS, Kapoor R, Pradeep R, Kapoor VK, Saxena R, Kaushik SP. Palliative surgical treatment of malignant obstructive jaundice. Eur 7 Surg Oncol 1994; 20: 580-4.

15 Bakkevold KE, Kambestad B. Morbidity and mortality after radical and palliative pancreatic cancer surgery. Risk factors influencing the short-term results. Ann Surg 1993; 217: 356-68.

16 Su CH, P'eng FK, Lui WY. Factors affecting morbidity and mortality in biliary tract surgery. World $\mathcal{F}$ Surg 1992; 16 536-40.

17 Wait RB, Kahng KU. Renal failure complicating obstructive jaundice. Am ₹ Surg 1989; 157: 256-63.

18 Hunt DR, Allison MEM, Prentice CRM, Blumgart LH. Endotoxaemia, disturbance of coagulation, and obstructive jaundice. Am $\mathcal{F}$ Surg 1982; 144: 325-9.

19 Grande L, Garcia-Valdecasas JC, Fuster J, Visa J, Pera C. Obstructive jaundice and wound healing. Br $\mathcal{F}$ Surg 1990 77: $440-2$.

20 Wilkinson SP, Moodie H, Stamatakis JD, Kakkar W, Williams R. Endotoxaemia and renal failure in cirrhosis Williams R. Endotoxaemia and renal failure in
and obstructive jaundice. $B M \mathcal{F} 1976 ; 2: 1415-8$.

21 Wardle EN, Wright NA. Endotoxin and acute renal failure associated with obstructive jaundice. $B M F 1970 ; 4$ $472-4$

22 Greve JW, Gouma DJ, Soeters PB, Buurman WA Suppression of cellular immunity in obstructive jaundice is caused by endotoxins: a study with germ free rats. Gastroenterology 1990; 98: 478-85.

23 Diamond T, Rowlands BJ. Endotoxaemia in obstructive jaundice: the role of gastrointestinal bile flow. Surg Res Comm 1989; 5: 11-6.

24 Clements B, Halliday I, Erwin P, McCaigue M, Barclay GR Rowlands BJ. Conclusive evidence for endotoxaemia in biliary obstruction. Gut 1993; 34 (suppl 4): F223.

25 Bemelemans MHA, Greve JW, Gouma DT, Buurmann WA. Cytokines, tumour necrosis factor and interleukin- 6 in experimental biliary obstruction in mice. Hepatology 1992 15: $1132-6$.

26 Beutler B, Cerami A. Cachectin: more than a tumor necrosis factor. $N$ Engl $\mathcal{F}$ Med 1987; 316: 379-35.

27 Molloy RG, Mannick JA, Rodrick ML. Cytokines, sepsis and immunomodulation. Br f Surg 1993; 80: 289-97.

28 Deitch EA. Simple intestinal obstruction causes bacterial translocation in man. Arch Surg 1989; 124: 699-701.

29 Deitch EA. Intestinal permeability is increased in burn patients shortly after injury. Surg 1990; 107: 411-6.

30 Baker JW, Deitch A, Ma L, Berg R. Haemorrhagic shock promotes the systemic translocation of bacteria from the gut. F Trauma 1988; 28: 896-906.

31 Deitch EA, Berg RD, Specian R. Endotoxin promotes the translocation of bacteria from the gut. Arch Surg 1987 122: 185-90

32 Ma L, Specian RD, Berg RD, Deitch EA. Effects of protein malnutrition and endotoxin on the intestinal mucosal barrier to the translocation of indigenous flora in mice. Paren Enteral Nutr 1989; 13: 572-8.

33 Berg RD. Bacterial translocation in the immunocompromised host. Microecol Ther 1989; 18: 43-9.

34 Berg RD, Wommack E, Deitch EA. Immunosuppression and intestinal bacterial overgrowth promote bacterial translocation. Arch Surg 1988; 123: 1359-64.

35 Bergesen $O$, Schjonsby $H$, Andersen KJ, Schjerven $L$. Intestinal epithelial function and villous surface area in rats with bile fistulae. Scand $\mathcal{F}$ Gastroenterol 1987; 22. $731-6$.
36 Xu D, Oi D, Guillory D, Cruz N, Berg R, Deitch EA. Mechanisms of endotoxin-induced intestinal injury in a hyperdynamic model of sepsis. I Trauma 1993; 34: 676-83.

37 Deitch EA, Specian RD, Berg RD. Endotoxin induced bacterial translocation and mucosal permeability: Role of xanthine oxidase, Complement activation and macrophage production. Crit Care Med 1991; 19: 785-91.

38 Burke V, Stone DE, Beaman J, Gracey M. Effects of biliary diversion on intestinal microflora in the rat. $7 \mathrm{Med}$ Microbiol 1977; 10: 241-4.

39 Slocum MM, Sittig KM, Specian RD, Deitch EA. Absence of intestinal bile promotes bacterial translocation. $\mathrm{Am}$ Surg 1992; 58: 305-10.

40 Vane DW, Redlich P, Weber T, Leapman S, Siddiqui AR, Grosfield $\mathrm{JL}$. Impaired immune function in obstructive jaundice. $\mathcal{F}$ Surg Res 1988; 45: 287-93.

41 Pinto $M$, Kaplun A. Immune status in mice with experimental biliary obstruction. Clin Immunol Immunopathol 1980; 16: 396-405.

42 Roughneen PT, Drath DB, Kulkarni A, Rowlands BJ Impaired non-specific cellular immunity in experimental cholestasis. Ann Surg 1987; 206: 578-82.

43 Feduccia TD, Scott-Conner CE, Grogan JB. Profound suppression of lymphocyte function in early biliary obstruction. Am f Med Sci 1988; 96: 39-44.

44 Greve JW, Gouma DJ, Soeters PB, Buurman WA Suppression of cellular immunity in obstructive jaundice is caused by endotoxins: A study with germ free rats. Gastroenterology 1990; 77: 478-85.

45 Gautreaux MD, Deitch EA, Berg RD. T-Lymphocytes in host defense against bacterial translocation from the gastrointestinal tract. Infect Immun 1994; 62: 2874-84.

46 Deitch EA, Xu DZ, Qi L, Berg RD. Bacterial translocation from the gut impairs systemic immunity. Surgery 1991; 109: 269-76.

47 Megison SM, Dunn CW, Horton JW, Chao H. Effects of relief of biliary obstruction on mononuclear phagocyte system function and cell mediated immunity. $\mathrm{Br} \mathcal{F}$ Surg 1991; 78: 568-71.

48 Scott-Conner CE, Grogan JB. The pathophysiology of biliary obstruction and its effect on phagocytic and immune function. $\mathcal{F}$ Surg Res $1994 ; 57: 316-36$.

49 Wells CL, Maddaus MA, Simmons RL. Proposed mechanisms for the translocation of intestinal bacteria. Rev Infect Dis 1988; 10: 958-79.

50 Nieuwenhuizen GA, Haskel Y, Lu Q, et al. Macrophage elimination increases bacterial translocation and gutorigin septicaemia but attenuates symptoms and mortality rate in a model of systemic inflammation. Ann Surg 1993; 218: 791-9.

51 Iwanga S, Morita T, Harada T, et al. Chromogenic substrates for horseshoe crab clotting enzyme. Its application for the assay of bacterial endotoxins. Haemostasis 1978; 7: 183-8.

52 Kocsar LT, Bertok L, Varteresz V. Effect of bile acids on the intestinal absorption of endotoxin in rats. $\mathcal{F}$ Bacterio 1969; 100: 220-3.

53 Cebra JJ, Kamat R, Gearhart P, et al. The secretary IgA system of the gut. Ciba Found Symp 1977; 46: 5-28.

54 Spaeth G, Gattwald T, Specian RD, Mainous MP Berg RD, Deitch EA. Secretory Immunoglobulin A, intestinal mucin and mucosal permeability in nutritionally induced bacterial translocation in rats. Ann Surg 1994; 220: $798-808$

55 Hentges DJ. Role of the intestinal microflora in host defenses against infection. In: Hentges DJ, ed. Human intestinal microflora in health and disease. New York: Academic press, 1983: 311-32.

56 van Der Waiij D. Colonisation resistance of the digestive tract - Mechanisms and clinical consequences. Nahrung 1987; 31: 507-17.

57 McNeill NI, Cummings JH, James WPT. Short chain fatty acid absorption by the human large intestine. Gut 1978; 9. 819-22.

58 Cruz N, Lu O, Alvarez X, Deitch EA. Bacterial translocation is bacterial species dependent: results using the human Caco-2 intestinal cell line. $\mathcal{F}$ Trauma 1994; 36: 612-6.

59 Katouli M, Bark T, Ljungqvist O, Svenberg T, Mollby R. Composition and diversity of intestinal coliform flora influences bacterial translocation in rats after haemorrhagic stress. Infect Immun 1994; 62: 4768-74.

60 Katz S, Grosfeld JC, Gross K, et al. Impaired bacterial clearance and trapping in obstructive jaundice. Ann Surg clearance and trappir

61 Floch MH, Gerschengoren W, Elliott S, Spiro HM. Bile acid inhibition of the intestinal microflora. A function for

62 Williams RC, Showalter R, Kern F. In vivo effect of bile salts and cholestyramine on intestinal anaerobic bacteria. Gastroenterology 1975; 69: 483-91.

63 Andersson R, Tranberg K-G, Lillienau J, et al. Influence of individual bile acids in Escherichia coli peritonitis. Scand $\mathcal{f}$ Gastroenterol 1990; 25: 1129-36.

64 Cahill CJ. Prevention of post-operative renal failure in patients with obstructive jaundice - The role of bile salts. Br F Surg 1983; 70: 590-5.

65 Pain JA, Bailey ME. Prevention of endotoxaemia in obstructive jaundice - A comparative study of bile salts. HPB Surg 1988; 1: 21-7.

66 Ding JW, Andersson R, Soltesz V, Willen R, Bengmark S. The role of bile and bile acids in bacterial translocation in obstructive jaundice in rats. Eur $\mathcal{F}$ Surg 1993; 25: 11-9. 